\title{
Effect of Carbonized Tangerines Prepared Using Plasma as Fertilizer: Case Study-Lettuce Farming
}

\author{
Soo-Young Moon ${ }^{1}$, Hyeon Soo Kim ${ }^{1} * \mathbb{E}$, Daehee Jang ${ }^{1}$ and Ji-Young Lee ${ }^{2}$ \\ 1 Department of Building Research, Korea Institute of Civil Engineering and Building Technology, \\ Goyang 10223, Korea; symoon@kict.re.kr (S.-Y.M.); zzan1113@kict.re.kr (D.J.) \\ 2 Department of Environmental Management, Korea Environment Institute, Sejong 30147, Korea; \\ leejy@kei.re.kr \\ * Correspondence: hskim1@kict.re.kr
}

check for updates

Citation: Moon, S.-Y.; Kim, H.S.; Jang D.; Lee, J.-Y. Effect of Carbonized Tangerines Prepared Using Plasma as Fertilizer: Case Study—Lettuce Farming. Sustainability 2022, 14, 243. https://doi.org/10.3390/su14010243

Academic Editors: Simeng Li and Ana Méndez

Received: 25 November 2021 Accepted: 23 December 2021 Published: 27 December 2021

Publisher's Note: MDPI stays neutral with regard to jurisdictional claims in published maps and institutional affiliations.

Copyright: (C) 2021 by the authors. Licensee MDPI, Basel, Switzerland. This article is an open access article distributed under the terms and conditions of the Creative Commons Attribution (CC BY) license (https:// creativecommons.org/licenses/by/ $4.0 /)$.

\begin{abstract}
This study investigates the soil chemical changes and crop growth characteristics after treatment with carbonized tangerines prepared using plasma. To determine the effect of the carbonized tangerines on crop, four test plots were treated with chaff charcoal or different ratios of coco peat and carbonized tangerines. Lettuce was grown on the plots, and the chemical changes in soil and physical changes in the lettuce were observed. Chemical changes in the soil before and after the carbonized tangerine treatments were very similar to those before and after chaff charcoal treatment. Lettuce leaf length, width, weight, and count in carbonized tangerine-treated plots significantly increased than those in the untreated plot. Our results found that the carbonization of tangerines using plasma can be a good alternative for processing many by-products generated during cultivation. In addition, the possibility of using carbonized tangerines as biochar has been explored.
\end{abstract}

Keywords: biochar; by-product utilization; carbonized tangerines; plasma technology

\section{Introduction}

Following the ban on the oceanic discharge of waste, such as food waste, sludge, and drinking water, in 2013 [1], food waste disposal and resource conversion has become an important national topic. It was selected as one of the Korean government's top 10 multi-ministerial tasks for resolving social issues in 2014. Currently, operating landfills are exceeding the food waste capacity and finding new landfill sites is difficult due to the NIMBY (Not in My Back Yard) phenomenon. Accordingly, waste needs to be recycled as a resource. Food waste is often generated in houses and restaurants, whereas skins, seeds, and stems are generated while processing agricultural products in farms or food factories. This is one of the issues that require attention for disposal, for example, by incineration and landfill. In particular, crops with high acidities, such as tangerines, can place a significant burden on the processing machinery because of corrosion. Therefore, this is a very critical issue in a general food waste disposal plan.

There are several useful aspects of treating food wastes by carbonization. First, it is possible to reduce the odor and secondary pollution caused by spoilage because large amounts are processed in a short time. Moreover, since the by-products after carbonization are carbon crystals, it has many uses through further processing.

In general, two problems arise during food waste processing and recycling. Food contains a high amount of salt, which must be removed to utilize food waste as a fertilizer. Moreover, since various types of food are mixed and discarded, it is difficult to obtain by-products with the same composition because the basic properties are not constant even after processing. Thus, the carbonized material has the same composition and uniform quality when the waste is generated from a single crop; therefore, it is convenient to use it as barbecue charcoal or in beauty products. 
The purpose of this study is to explore ways of utilizing carbonized tangerines prepared using plasma as biochar. We examined the changes in the chemical composition of the soil after adding carbonized tangerines and its effect on crop growth to determine whether carbonized tangerines can be used as mixed soil similar to biochar, or as a soil improvement additive, in an attempt to present a method of utilizing the organic waste generated in farms and food processing plants as a resource. The objectives of this study are to determine if carbonized tangerines are toxic, confirm the physical elements present in the carbonized tangerines to verify their utility for plant growth, and analyze the chemical composition of soil treated with carbonized tangerines as an input to see if they help improve soil performance during agriculture.

\section{Literature Review}

Previous studies using carbonization technology have primarily focused on biochar production and application, the effects of using biochar carbonized from specific individuals, and the environmental impact of biochar. These studies have been performed since early 2000s, when biochar research began and have gradually developed in several directions.

\subsection{Biochar Production and Use}

Biochar is a material obtained from biomass carbonization, which reduces greenhouse gas by fixing carbon released from decomposing biomass and is mainly used as an adsorbent or soil conditioner as porous media. Biochar is made by biomass pyrolysis. The carbon fixation capacity increases with the increased pyrolysis temperature, thus producing less biochar [2].

During biochar production, specific chemicals may be added to improve the biochar to maximize the realization of the performance for a specific purpose. The heavy metal adsorbing capacity of hydrogen peroxide-enhanced biochar is about 20 times higher than that of unimproved biochar and activated carbon $[3,4]$. One study also showed that coating the biochar surface with chitosan is effective in heavy metal adsorption and as a soil conditioner [5]. Urea-modified biochar adsorbs phenol [6] and can be used for removing organic pollutants after transformation using methanol [7]. Some studies have shown that the methylene blue adsorption capacity of graphene-coupled biochar was improved by more than 20 times [8,9].

In some cases, clay-based materials are added to improve the biochar. Distributing clay particles in the biochar [10] or modifying it with manganese oxide [11] increases heat resistance. Additionally, when biochar is combined with magnesium, the phosphorus adsorption rate is superior to that of other adsorbents [12]. Studies have also shown that the copper adsorption rate increases by more than eight times after manganese oxide addition [13].

\subsection{Verification of the Effectiveness of Biochar Made with Specific Materials}

Various studies on the possibility of carbonized by-products for agricultural application have also been undertaken. For example, a study observed the chemical characteristics of tomatoes grown on a different medium after sowing and germinating tomato seeds in a medium developed using carbonized chestnut chips [14]. The changes in growth and yield of potatoes and cabbages using biochar have been studied [15]. These studies found a significant increase in the yield of certain plants, for example, potatoes, when using biochar. Carbon sequestration calculated according to the change in biochar reported the optimal biochar application rate for tomato yield to be $0.05 \%$ [16].

Several studies have also focused on the physicochemical properties of carbonized samples. These investigations provided an appropriate carbonization temperature for agricultural use by evaluating soil productivity and fertility when using carbide or removed odor using carbonized chaff [15]. Carbonized chaff has superior impregnation properties for alkaline substances than activated carbon, and chemical adsorption improved after reaction 
with hydrogen sulfide, thus improving the removal performance [17]. Furthermore, coir and bottom ash were mixed in various ratios, and the differences in physical and chemical performance were identified to explore whether the bottom ash of coal ash, which is generated as a by-product in thermal power plants, can be used as a topsoil material [18].

Moreover, the changes in soil chemical properties after using biochar in corn cultivation have been monitored, and the amount of carbon sequestration by reducing the nitro-gen content when using biochar pallet has been calculated [19]. Nitrogen reduced by approximately $60 \%$ when growing corn, which is a positive result because it contributes to the reduction of $\mathrm{CO}_{2}$ when carbonizing waste.

In addition to these studies on the effects of biochar on a single crop, various studies have focused on the effects of carbonizing various by-products (particularly manure) discharged from raising livestock, such as cows and chickens, and using them as biochar on sandy soil [20-22].

\subsection{Environmental Impact of Biochar}

With the development of carbonization technology and increasing interest in biochar, studies have regularly examined whether carbonized by-products perform well when used in agriculture and fuel. Since the early 2000s, several studies have focused on the effects of biochar on grain cropping and soil change [23-27].

Biochar, unlike carbon-neutral biomass, is known for its substantial carbon-negative carbon sequestration, which helps to fix atmospheric carbon in the soil. In addition, biochar may exist for a long period without emitting carbon into the atmosphere because of little microbial decomposition and conversion [28]. The carbon fixation effect of biochar is significantly higher than that of other methods as it can fix $420-450 \mathrm{~kg}$ carbon per ton carbonization [29].

According to a study that quantitatively analyzed the sustainability of biochar under a global carbon-reduction scenario, the carbon sequestration effect is about $10 \%$ higher during biochar production using degradation by-products (e.g., biogas) as an energy source than that using biomass as a direct energy source [30]. Another study found that the effect of carbon sequestration was $33.2 \%$ higher when tree branches and other materials discarded from farms were carbonized than that when forests were left unattended [31].

Some studies have shown that biochar treatment on agricultural land reduces the amount of $\mathrm{N} 2 \mathrm{O}$ emitted from the soil by about $15 \%$ [32]. A review of the various existing literature on biochar has provided a comprehensive insight into how biochar affects N2O and $\mathrm{CH} 4$ [33]. Discussions on the impact of biochar in the environment have been ongoing for a long time, and many studies have aimed to determine their effectiveness in reducing greenhouse gas emission. A greenhouse experiment reported significant $\mathrm{N} 2 \mathrm{O}$ emission reduction [34]. Moreover, $1-2 \%(w / w)$ biochar application also reduces $\mathrm{N} 2 \mathrm{O}$ emission [35,36]. However, in some studies, no differences were observed or $\mathrm{N} 2 \mathrm{O}$ emissions increased from biochar amended soils [37-42]. Various studies focusing on the effect of biochar on CH4 absorption reported both positive and negative outcomes. Biochar implementation may also reduce the Greenhouse Gas (GHG) intensity per unit of agricultural product by reducing $\mathrm{N}$-fertilizer and labile-C inputs at unaltered or increased yields [43]. Moreover, it may considerably reduce the GHG intensity of rice crop production, particularly in acidic soils [44]. They also increased crop growth by up to $24-28 \%$, although the effect of $\mathrm{CH} 4$ absorption after biochar application to soil was questionable [45]. Some studies have shown that biochar can replace antibiotic treatment when mixed with $0.3-1 \%$ chicken and duck feed, and biochar plus Lactobacilli can reduce the use of antibiotics and indirectly help reduce greenhouse gas emissions $[46,47]$.

Studies have shown that biochar is also conducive to the growth of soil microorganisms due to the micro pores and inorganic supply capacity in biochar, which helps the growth of soil microorganisms and plays the role of microbial habitat, eventually increasing crop productivity [28]. Glaser et al. have reported that injecting biochar into the soil can increase agricultural productivity by a factor of two [48]. 


\subsection{Application of Plasma for Production of Biochar}

Since the late 2010s, various cases of using plasma to make biochar have appeared. Various applications are being made from the case of treating biomass and effluent sludge waste $[49,50]$ to use it as a fertilizer to the case of using it to remove specific elements such as mercury [51]. When biochar is produced using plasma, research is mainly focused on using it as a fertilizer through rapid processing of organic waste. In the case of raw biochar, the efficiency is very low, so biochar is produced as a high-efficiency product using various technologies, and one of them is to use plasma to produce biochar [52]. Using slow pyrolysis and thermal plasma, it was possible to produce high value-added Biochar rich in potassium $(\mathrm{K})$ and phosphorus $(\mathrm{P})$ [49]. In addition, if plasma is used, more than $95 \%$ of bio hydrogen can be generated, which is very efficient and can bring a new aspect to biomass and waste treatment [53].

\section{Materials and Methods}

\subsection{Research Limitations}

In Korea, while the fertilizing function is important when developing fertilizers, their performance is evaluated mainly based on the fact that its use will not cause soil and groundwater contamination [54,55]. Therefore, whether the fertilizers contain heavy metals must be evaluated, despite their outstanding fertilizing performance. In the case of fuel development using waste, there is a regulation that the lower calorific value must always be measured and approved for use before the fuel is used [56]. Moreover, using food waste as fuel is prohibited by law (Waste Management Act) in Korea; therefore, this study focused on utilizing the carbonized tangerines as a fertilizer.

\subsection{Statistical Analysis}

The experiment results were analyzed through the GLM process and ANOVA analysis using SAS version 9.1 (Statistical Analysis System; SAS Institute Inc.; Cary, NC, USA) and comparisons between means were made at the level of significance of $p<0.05$, using Duncan's multiple range test (DMRT) method for statistical processing.

\subsection{Plasma Use}

Plasma, the fourth ionized state after solid, liquid, and gas, is the aggregate of neutral gases, ions, and electrons that occupy $95 \%$ of the universe. Plasma technology, which freely uses various desired temperatures from at least $120^{\circ} \mathrm{C}$ to $>1000{ }^{\circ} \mathrm{C}$, is now being studied as a tool for the carbonization of waste such as food. The plasma temperature used in this study was approximately $1300{ }^{\circ} \mathrm{C}$ (by which the incinerator containing the waste was heated to $200-300{ }^{\circ} \mathrm{C}$ ), and the fallen tangerines were rapidly pyrolyzed for their carbonization. The carbonizer is a compact device that allows plasma to be used in residential areas and treats food waste per day in units of $100 \mathrm{~kg}$ [57]. The reduction rate is approximately $98 \%$, and approximately $3 \mathrm{~kg}$ of by-products were generated by carbonizing $200 \mathrm{~kg}$ waste.

Existing food waste was collected and transported from the source to the treatment plant and partially recycled and reprocessed and, subsequently, a major portion was disposed on land or at sea. However, with the ban on waste dumping at sea since 2013, efforts are being made to fundamentally reduce waste via methods such as volume-rate garbage disposal systems, but there are limitations. In Korea, the food waste treatment method, which was used as feed for livestock, has been banned since July 2019. The use of food waste as wet/dry feed was legally discontinued in Korea in 2017 due to the risk of avian influenza (AI) or pig foot and mouth disease, because the Ministry of Agriculture, Food and Rural Affairs viewed that these diseases are caused by supplying livestock with food and beverage leftovers as feed [58].

Therefore, it was necessary to re-examine the fundamental treatment method for recycling food waste. In order to reduce food waste, the treatment was carried out by methods such as heat-drying and microbial fermentation; however, very few processes 
recycled the by-products generated after treatment, so the by-products became secondary waste. Accordingly, various methods are being devised for the treatment of wastes within the source itself using advanced technologies. One of these technologies is food waste carbonization, using plasma and studies using plasma to carbonize food waste for use as fertilizer or fuel have attracted attention. Previously, plasma was used in large power plant facilities to treat a large amount of municipal waste, sewage sludge, and livestock manure. Using the gas and steam generated while treating a large amount of waste with plasma, a gas engine and steam turbine were driven to generate highly efficient electricity [59]. Currently, equipment miniaturization and stabilization are being studied for use in residential complexes, hospitals, hotels, and commercialization [57].

One of the difficulties of using organic compost is that plant roots are damaged and soil contaminants and leachate are generated when unripe compost is used. Therefore, using organic compost is avoided in the field. However, there is little concern about carbonizing unripe materials as the high-temperature flame (approximately $1300{ }^{\circ} \mathrm{C}$, incinerator temperature: $200-300{ }^{\circ} \mathrm{C}$ ) removes all remaining elements and leaves only $\mathrm{C}$, which is expected to be used as compost and high-temperature fuel. A calorific value test on the carbonized tangerine reported that $5050-5500 \mathrm{kcal} \mathrm{kg}^{-1}$ was emitted when burned as fuel. Considering that the calorific value standard for solid fuel is generally $3000 \mathrm{kcal} \mathrm{kg}^{-1}$ or more, the calorific value of carbonized tangerine was significantly high.

\subsection{Methods}

\subsubsection{Experiment Process}

This study investigated the chemical changes and growth characteristics of crops after using $3 \mathrm{~kg}$ of carbonized tangerines, prepared by carbonizing $200 \mathrm{~kg}$ of fallen tangerines using plasma, as a fertilizer. More than $200 \mathrm{~kg}$ of fallen tangerines were collected from a tangerine farm on Jeju Island and after carbonized using high-temperature plasma to produce $3 \mathrm{~kg}$ of carbonized by-products (Figure 1). Since the tangerines had various contaminants such as soil, they were washed before carbonizing to remove the harmful ingredients that may be present on the fallen tangerines.

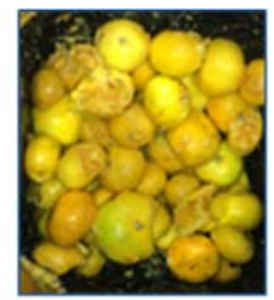

$200 \mathrm{~kg}$ Fallen tangerines
Using Plasma : Temperature $1300^{\circ} \mathrm{C}$

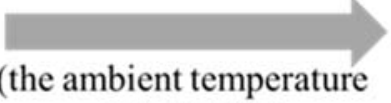
: $200-300{ }^{\circ} \mathrm{C}$ )

Figure 1. Tangerine carbonization using plasma.

The purpose of the experiment was to verify the effectiveness of carbonized tangerines as a by-product fertilizer. The soil was treated with 10:0, 7:3, 5:5, and 0:10 carbonized tangerines: coco peat (ratio by volume ratio) and the plant growth changes in each soil was observed (first step). Then, the chemical changes in the most efficient mix- and chaff charcoal-treated soil were compared (second step; Figure 2).

The soil was collected before and after crop cultivation using carbonized tangerines, and the chemical composition was analyzed according to the standard analysis methods, including the standard method for soil chemical analysis by the Rural Development Administration [60] and the standard method for examination of soil pollution by the Ministry of Environment [54] in Korea. To determine the change in yield, a growth characteristics survey was conducted following the Rural Development Administration standards [55]. To investigate the effects of carbonized tangerines on crop yield, four test plots were established with different ratios of coco peat and carbonized tangerine mixture in the soil, 
treated with even fertility, and a control plot was treated with chaff charcoal. Lettuce was used as the growing crop.

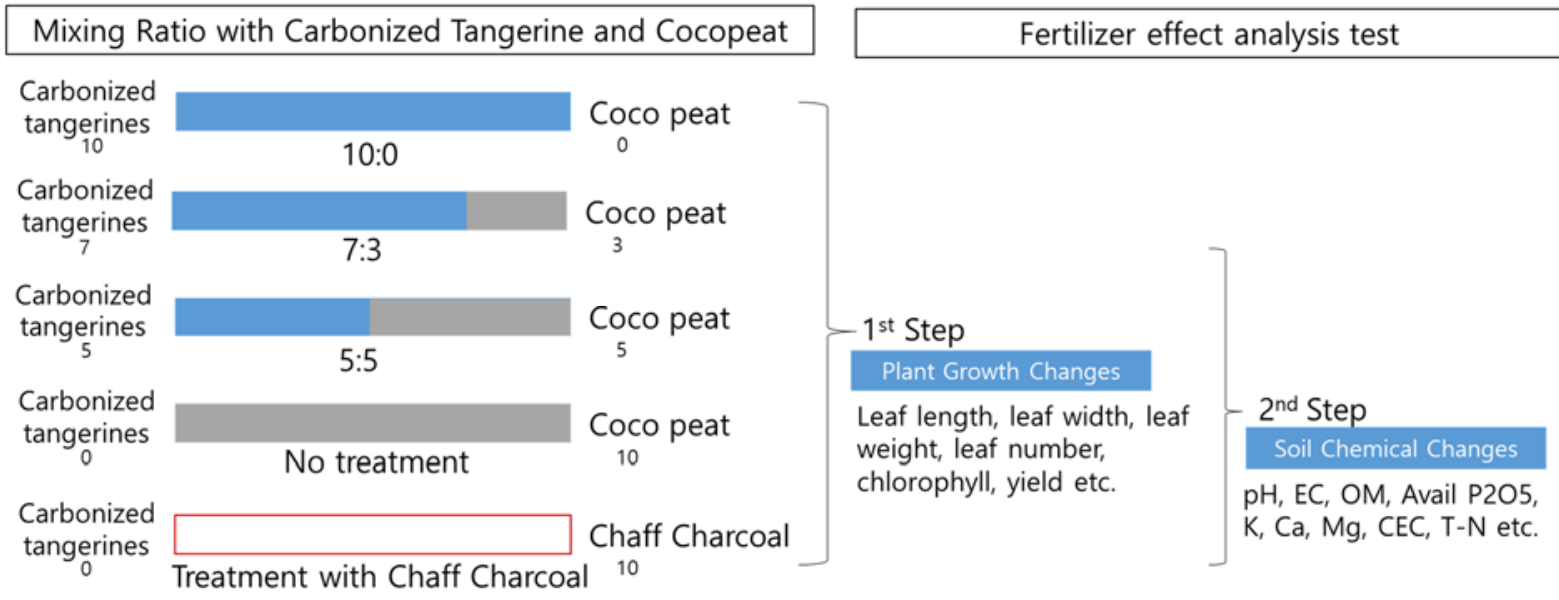

Figure 2. Plant experiment process through plant growth analysis on soil fertilized with carbonized tangerines blended with coco peat.

\subsubsection{Analysis of the Properties of Carbonized Tangerine By-Product}

Particle size analysis of carbonized tangerine by-product: A particle size analysis was performed using sieves to determine the properties of the carbonized tangerines. Standard sieves verified according to ISO 3310 and BS410 regulations were used, and the particle size distribution according to the weight was analyzed using an electronic balance for the particles filtered through each sieve. Particle size influences drainage when applied to the soil. The particle size of the carbonized tangerines was determined to ensure no drainage hindrance when applied to the soil.

Chemical properties of carbonized tangerines: The generation of heavy metals and other substances during tangerine carbonization using plasma should be examined. The changes in the chemical properties of the carbonized tangerines used in the study were determined following the official standard required for the examination of commercial fertilizer prior to the test. The strict standard for the ratio of salt, moisture, nitrogen, and harmful components such as heavy metals must be requirement. when commercializing fertilizers in Korea [20].

\subsubsection{Test for Fertilizer Effect}

Test for chemical effect: To explore the agricultural use of carbonized tangerines, an experimental plot was established to determine the possibility of mixed soil or soil conditioner. A fertilizer injury/fertilizer efficiency experiment was conducted on the experimental plot by mixing carbonized tangerines with coco peat in different ratios, which is most easily obtained in Asia. Water content, water loss, heavy metal ratio, and plant growth were tested. The comparative experiment with chaff charcoal, which is a commercialized product estimated to exhibit similar performance to an organic by-product, was conducted using the same process.

To investigate the change in soil chemical properties after applying the carbonized tangerine by-product, the soil composition was analyzed before and after cultivation. After collecting and mixing the soil at more than three points for each treatment plot, it was dried in shade and the $\mathrm{pH}$ (acidity), electrical conductivity (EC), available phosphorus, organic matter $(\mathrm{OM})$, exchangeable cation, soil texture, total nitrogen ( $\mathrm{T}-\mathrm{N})$, and cati-on-exchange capacity (CEC) were analyzed (Table 1$)$. 
Table 1. Chemical properties of the analysis and equipment used.

\begin{tabular}{ccc}
\hline Item & Method & Equipment \\
\hline $\mathrm{pH}(1: 5)$ & $1: 5$ Distilled water extraction & $\mathrm{pH}$ meter \\
$\mathrm{EC}\left(\mathrm{dS} \mathrm{m}^{-1}\right)$ & $1: 5$ Distilled water extraction & EC meter \\
Available phosphorus $\left(\mathrm{mg} \mathrm{kg}^{-1}\right)$ & Lancaster & UV/Vis spectrometer \\
$\mathrm{OM}\left(\mathrm{g} \mathrm{kg}^{-1}\right)$ & Tyurin & Automatic titrator \\
$\mathrm{K}, \mathrm{Ca}, \mathrm{Mg}_{\left(\mathrm{cmol}^{-}(+) \mathrm{kg}^{-1}\right)}$ & 1N-NH $\mathrm{OAc}_{4} \mathrm{OAc}$ & ICP-OES \\
Soil texture & Hydrometric method & Hydrometer \\
$\mathrm{T}-\mathrm{N}$ & Total analysis & Elemental analyzer \\
$\left.\mathrm{CEC}\left(\mathrm{cmol}^{-1}\right) \mathrm{kg}^{-1}\right)$ & Brown & ICP-OES \\
\hline
\end{tabular}

CEC: cation-exchange capacity, EC: electrical conductivity, OM: organic matter, T-N: total nitro-gen., ICP-OES: Inductively coupled plasma-optical emission spectrometry.

Test for change in plant growth: To determine the crop yield, a growth characteristics survey was conducted following the Korean Government Standard [56]. The growth survey for leaf length, leaf width, weight (yield amount), count, fertilizer-injury ((O-5)z)and chlorophyll content was conducted once after harvesting.

Various factors, such as climatic conditions, soil type, and land fertility that affect the growth of crops, can be reflected in plant growth. Since these factors are variables that can have several effects on studies attempting to validate fertilizer performance, we attempted to eliminate these variables to the greatest extent possible. Therefore, soil that has a flat topography, neat shape, uniform soil fertility, and guarantees harvest even in flood or drought, was selected. In particular, a difference in soil fertility was prevented by avoiding areas previously used as a road or compost area. Therefore, for this study, a greenhouse located in Jincheon-ga, Sinbuk-eup, Chuncheon-si, Gangwon-do was selected to control the variables mentioned earlier. The greenhouse for this test was selected following the fertilizer prescription standard for each crop by the Korean Government Standard [50]; the topography is flat, and the soil is uniform and unaffected by flood or drought. Red leaf lettuce was used as a test crop. A randomized block design method was used for the batch method, repeated thrice, and the surveyed values were averaged.

The main survey item of the test was growth survey by treatment plot. The growth characteristics of the lettuce were investigated considering leaf length $(\mathrm{cm})$, width $(\mathrm{cm})$, weight (g), count (no./plant), fertilizer-injury ((O-5)z) and chlorophyll content (SPAD).

For cultivation test, lettuce saplings grown equally under the same conditions in a greenhouse for the experiment were used. To determine the measurement results for each condition, the mean and standard deviation were calculated using the IBM SPSS statistics program version 19, and a one-way ANOVA was performed. The significance was tested using DMRT. Additional statistical processing was performed using the Microsoft Excel 2017 program.

The treatment area for this test was a rectangular per test plot. Planting was carried out at $30 \mathrm{~cm}$ intervals in a row per treatment plot, with three repetition plots with $1.6 \mathrm{~m}$ widths and $4.3 \mathrm{~m}$ lengths $\left(20.64 \mathrm{~m}^{2}\right.$, a section of 2.68 width to length ratio). The distance between treatment plots was $50 \mathrm{~cm}$.

A chlorophyll meter (SPAD-502 plus, Konica Minolta; Japan) was used to measure the chlorophyll content of leaf non-destructively. The lettuce leaf width was measured uniformly using a ruler, and the leaf weight was measured using a scale.

\section{Results}

More than half the particles were $2 \mathrm{~mm}$ or more and most were greater than $0.85 \mathrm{~mm}$ (Table 2), which are not identified as fine dust. 
Table 2. Particle size distribution of carbonized tangerines.

\begin{tabular}{cc}
\hline Sieve & Distribution (\%) \\
\hline $19 \mathrm{~mm}$ or more & 0.00 \\
$2 \mathrm{~mm}$ or more & 52.8 \\
$2-1.7 \mathrm{~mm}$ & 7.93 \\
$1.7-0.85 \mathrm{~mm}$ & 33.42 \\
$0.85-560 \mu \mathrm{m}$ & 0.05 \\
$560-250 \mu \mathrm{m}$ & 0.04 \\
$250-212 \mu \mathrm{m}$ & 0.06 \\
$212-106 \mu \mathrm{m}$ & 5.67 \\
$106 \mu \mathrm{m}$ or less & 0.03 \\
\hline
\end{tabular}

The results of the analysis are shown in Table 3. More than half the carbonized tangerines comprised carbon and $2.25 \%$ moisture, which was distributed minutely. The $\mathrm{pH}$ was approximately 7 (neutral) and most harmful ingredients were not detected.

Table 3. Analysis of the components of the carbonized tangerines.

\begin{tabular}{|c|c|c|c|}
\hline & omponents & Distribution & Baseline \\
\hline \multirow{14}{*}{$\begin{array}{l}\text { Harmless } \\
\text { ingredients } \\
(\%)\end{array}$} & $\mathrm{pH}(1: 5)(1: 10)$ & 7.01 & 70 or less \\
\hline & Organics to Nitrogen Ratio & 2.29 & 70 or less \\
\hline & Carbon & 57.48 & \\
\hline & Sulfur & 0.52 & 55 or less \\
\hline & Moisture & 2.25 & 55 or less \\
\hline & Phosphoric acid & 0.077 & - \\
\hline & Potassium (Kalium) & 0.96 & - \\
\hline & Lime & 0.046 & - \\
\hline & Magnesia & 0.022 & \\
\hline & Boron & 0.0082 & \\
\hline & Iron & 0.025 & \\
\hline & Manganese & 0.0021 & \\
\hline & Silicic acid & 0.47 & \\
\hline & Molybdenum & 0.00016 & 2 or less \\
\hline \multirow{8}{*}{$\begin{array}{l}\text { Harmful } \\
\text { ingredients } \\
\left(\mathrm{mg} \mathrm{kg}^{-1}\right)\end{array}$} & As $\left(\mathrm{mg} \mathrm{kg}^{-1}\right)$ & Not detected & 45 or less \\
\hline & $\mathrm{Cd}\left(\mathrm{mg} \mathrm{kg}^{-1}\right)$ & 0.29 & 5 or less \\
\hline & $\mathrm{Hg}\left(\mathrm{mg} \mathrm{kg}^{-1}\right)$ & Not detected & 2 or less 130 or less \\
\hline & $\mathrm{Pb}\left(\mathrm{mg} \mathrm{kg}^{-1}\right)$ & Not detected & 130 or less 250 or less \\
\hline & $\mathrm{Cr}\left(\mathrm{mg} \mathrm{kg}^{-1}\right)$ & 5.64 & 250 or less 360 or less \\
\hline & $\mathrm{Cu}\left(\mathrm{mg} \mathrm{kg}^{-1}\right)$ & 285.88 & 360 or less 45 or less \\
\hline & $\mathrm{Ni}\left(\mathrm{mg} \mathrm{kg}^{-1}\right)$ & 2.20 & 45 or less 1000 or less \\
\hline & $\mathrm{Zn}\left(\mathrm{mg} \mathrm{kg}^{-1}\right)$ & 23.60 & 1000 or less \\
\hline
\end{tabular}

The soil chemical change and plant growth change were comparatively analyzed among the untreated, different mix-treated, and chaff charcoal-treated (control) plots. The change between the untreated and 10:0 mix-treated plots is a comparison of changes depending on the presence or absence of carbonized material. Moreover, the changes among different mix-treated plots were also analyzed to verify whether they were mixing ratio-dependent. A comparison with the best performing plot allows the observation of the effect of commercially available chaff charcoal compared to no treatment. Accordingly, performance comparison with the carbonized material should be conducted in the future.

\subsection{Growth Characteristics and Lettuce Yield}

\subsubsection{Growth Characteristics in Different Mix-Treated Plots}

The leaf length, leaf width, leaf weight, and yield were the highest in the 10:0 mixtreated plot, while the chlorophyll content and leaf count in the 7:3 mix-treated plot were $15 \%$ higher than those in the 10:0 mix-treated plot (Figure 3). 


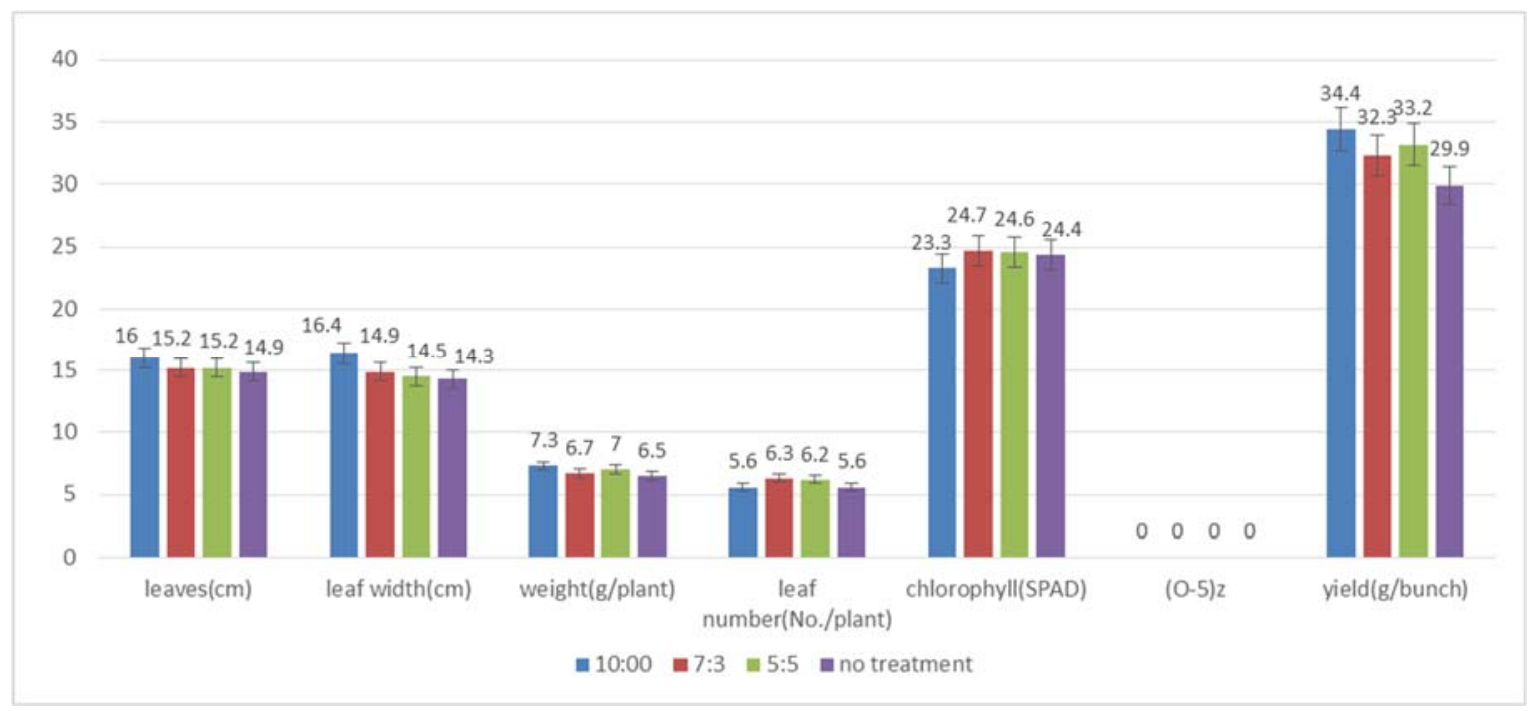

Figure 3. Growth characteristics and yield according to the mixing ratio. zMean Separation Within Columns by Duncan's Multiple Range Test at 5\% Level.

Figure 3 also shows that the growth was amplified visibly in terms of the leaf length, width, weight, and count. The leaf counts in 10:0 mix-treated and untreated plots were similar, while the length, width, and weight in the 10:0 mix-treated plots were higher by $7 \%, 14.7 \%$, and $12.3 \%$, respectively, than those in the untreated plots. This was similar to previously reported results that biochar increased crop growth by up to $25 \%$ [45].

Similarly, none of the treatments showed fertilizer injury $(\mathrm{O}-5) \mathrm{z}$, indicating that carbonized tangerine is not harmful for plants. Similar to the results of the previous assessment, carbonized tangerines favored plant root and leaf growth, overall increasing the product yield. However, the leaf weight, count, chlorophyll content, and yield were slightly higher in the 5:5 mix-treated plot than those in the 7:3 mix-treated plot. Considering this, an in-depth analysis is required.

Biomass is necessary to measure plant growth and harvesting a certain number of plant bodies and measuring their fresh or dry weight is a non-destructive way to measure biomass [61]. The fresh weight of lettuce grown on 10:0 mix-treated soil was more than 15\% higher than that grown on the untreated soil. Thus, 10:0 mix-treated soil was the best. Accordingly, the chemical components of this soil were compared with those of the un-treated and chaff charcoal-treated soils.

\subsubsection{Comparison among Untreated, 10:0 Mix-Treated, and Chaff Charcoal-Treated Plots}

Similar to the previous experiment, this experiment compared the untreated, 10:0 mix-treated, and chaff charcoal-treated (control) plots. Fertilizer injury (O-5)z was not generally observed in any plot, which indicated that carbonized tangerine is not harmful for plants. Figure 4 shows that the growth parameters and yield were higher in the 10:0 mix-treated plot than those in the untreated plot. However, the chlorophyll content of the 10:0 mix-treat plot was slightly lower than the untreated plot and the control plot only for chlorophyll.

The growth parameters and yield in both treated and control plots were significantly higher than those in the untreated plot, reflecting a visible difference, with the values in the treated plot being slightly higher than those in the control plot. A statistical significance was observed, and growth increased as the average growth value tended to increase in all treated plots than that in the untreated plot. Particularly, the yield was the highest in the treated and control plots. Figure 4 also shows that the yield in the 10:0 mix-treated plot is about $15 \%$ higher than that in the untreated plot and suggests that the properties of 10:0 mix and chaff charcoal are similar. Leaf growth was favored in the treated plot than the 
control plot, thereby favoring the movement of nutrients, as well as crop growth, which eventually increased commodity yield.

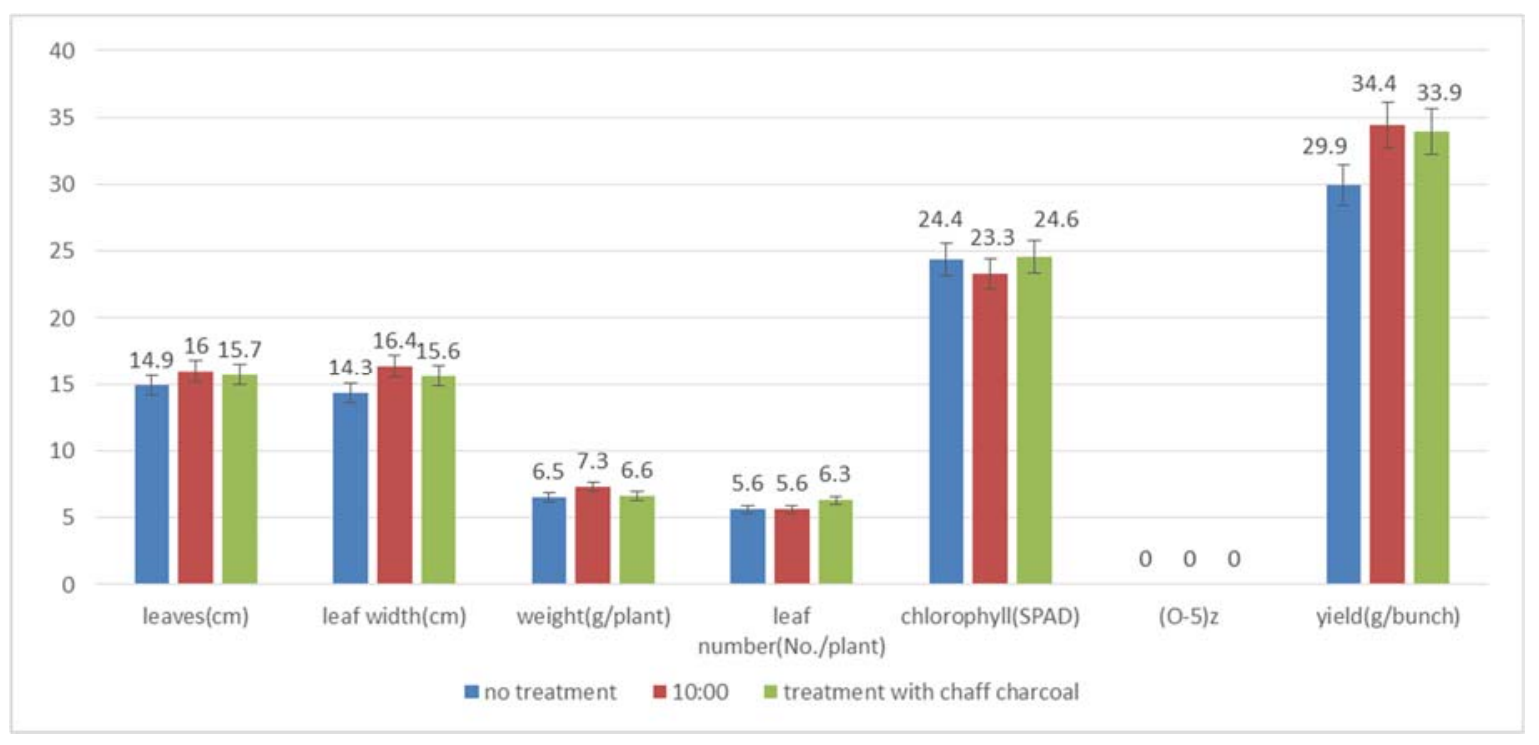

Figure 4. Growth characteristics and yield of untreated, 10:0 mix-treated, and chaff charcoal -treated plots. zMean Separation Within Columns by Duncan's Multiple Range Test at 5\% Level.

\subsection{Chemical Properties of Soil before and after Treatment}

The chemical properties of the soil used for testing were investigated (Table 1). To deter-mine the suitability of the chemical properties of the soil, standards for paddy soil and a cultivation facility in Korea [61] were reviewed. The results indicated that suitability varied by crop. When the present experiment was conducted in a small green house, the appropriate chemical composition range of the soil of the untreated, different mix-treated, and chaff-charcoal-treated plots was analyzed and compared. After growing the lettuce using carbonized tangerines, the chemical properties of the soil were analyzed. However, the soil quality improved or the difference was small in the treated plot than that in the untreated plot (Tables 4 and 5).

Table 4. Chemical properties of the soil before treatment.

\begin{tabular}{|c|c|c|c|c|c|c|}
\hline \multirow[b]{2}{*}{ Items } & \multirow[b]{2}{*}{ Unit } & \multicolumn{5}{|c|}{ Test Soil (Silent Loam) } \\
\hline & & Untreated & $\begin{array}{c}\text { 10:00 } \\
\text { Mix- } \\
\text { Treated }\end{array}$ & $\begin{array}{c}\text { 7:03 } \\
\text { Mix- } \\
\text { Treated }\end{array}$ & $\begin{array}{c}\text { 5:05 } \\
\text { Mix- } \\
\text { Treated }\end{array}$ & $\begin{array}{l}\text { Chaff } \\
\text { Charcoal- } \\
\text { Treated }\end{array}$ \\
\hline $\mathrm{pH}(1: 5)$ & - & 6.66 & 6.55 & 6.75 & 6.35 & 6.72 \\
\hline EC (1:5) & $\mathrm{d} S \mathrm{~m}^{-1}$ & 1.18 & 1.11 & 1.21 & 1.28 & 1.11 \\
\hline $\mathrm{OM}$ & $\mathrm{g} \mathrm{kg}^{-1}$ & 25.85 & 28.59 & 29.95 & 30.77 & 29.33 \\
\hline $\mathrm{P}_{2} \mathrm{O}_{5}$ & $\mathrm{mg} \mathrm{kg}^{-1}$ & 789 & 816 & 805 & 823 & 769 \\
\hline $\mathrm{K}$ & $\operatorname{cmol}(+) \mathrm{kg}^{-1}$ & 0.55 & 0.69 & 0.57 & 0.61 & 0.68 \\
\hline $\mathrm{Ca}$ & $\operatorname{cmol}(+) \mathrm{kg}^{-1}$ & 7.5 & 7.68 & 7.65 & 7.55 & 7.35 \\
\hline $\mathrm{Mg}$ & $\operatorname{cmol}(+) \mathrm{kg}^{-1}$ & 1.55 & 1.65 & 1.46 & 1.55 & 1.85 \\
\hline CEC & $\operatorname{cmol}(+) \mathrm{kg}^{-1}$ & 12.19 & 12.89 & 12.59 & 13.06 & 12.31 \\
\hline $\mathrm{T}-\mathrm{N}$ & $\%$ & 0.11 & 0.11 & 0.12 & 0.1 & 0.09 \\
\hline
\end{tabular}

CEC: cation-exchange capacity, EC: electrical conductivity, OM: organic matter, T-N: total nitrogen.

Each item was analyzed before and after treatment as a graph as described in Sections 4.2.1 and 4.2.2. 
Table 5. Chemical properties of the soil after treatment.

\begin{tabular}{|c|c|c|c|c|c|c|}
\hline \multirow{2}{*}{ Items } & \multirow{2}{*}{ Unit } & \multicolumn{5}{|c|}{ Test Soil (Silent Loam) } \\
\hline & & Untreated & $\begin{array}{c}\text { 10:00 } \\
\text { Mix- } \\
\text { Treated }\end{array}$ & $\begin{array}{c}\text { 7:03 } \\
\text { Mix- } \\
\text { Treated }\end{array}$ & $\begin{array}{c}\text { 5:05 } \\
\text { Mix- } \\
\text { Treated }\end{array}$ & $\begin{array}{l}\text { Chaff } \\
\text { Charcoal- } \\
\text { Treated }\end{array}$ \\
\hline $\mathrm{pH}(1: 5)$ & - & 6.75 & 6.63 & 6.79 & 6.55 & 6.68 \\
\hline EC (1:5) & $\mathrm{dS} \mathrm{m}^{-1}$ & 0.88 & 0.95 & 1.02 & 1.11 & 1.05 \\
\hline $\mathrm{OM}$ & $\mathrm{g} \mathrm{kg}^{-1}$ & 26.56 & 27.89 & 28.85 & 29.95 & 28.58 \\
\hline $\mathrm{P}_{2} \mathrm{O}_{5}$ & $\mathrm{mg} \mathrm{kg}^{-1}$ & 689 & 765 & 767 & 725 & 715 \\
\hline K & $\operatorname{cmol}(+) \mathrm{kg}^{-1}$ & 0.48 & 0.56 & 0.5 & 0.59 & 0.65 \\
\hline $\mathrm{Ca}$ & $\operatorname{cmol}(+) \mathrm{kg}^{-1}$ & 6.47 & 6.66 & 6.96 & 6.95 & 7.28 \\
\hline $\mathrm{Mg}$ & $\operatorname{cmol}(+) \mathrm{kg}^{-1}$ & 1.32 & 1.44 & 1.4 & 1.38 & 1.75 \\
\hline CEC & $\operatorname{cmol}(+) \mathrm{kg}^{-1}$ & 11.2 & 13.01 & 12.55 & 12.89 & 12.85 \\
\hline $\mathrm{T}-\mathrm{N}$ & $\%$ & 0.08 & 0.1 & 0.09 & 0.09 & 0.1 \\
\hline
\end{tabular}

CEC: cation-exchange capacity, EC: electrical conductivity, OM: organic matter, T-N: total nitrogen.

\subsubsection{Chemical Properties of Soil in Different Mix-Treated Plots}

The $\mathrm{pH}$ (1:5) and EC (1:5) did not change significantly, even after the experiment within the appropriate range (Figure 5). The $\mathrm{pH}$ gradually increased after the experiment and was closer to 7 (neutral). EC tended to decrease by about $0.1-0.2 \mathrm{dS} \mathrm{m}^{-1}$ after the experiment.

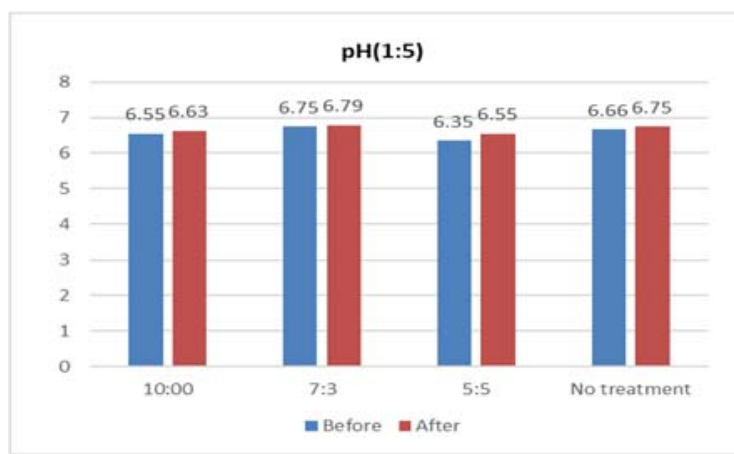

(a) $\mathrm{pH}(1: 5)$

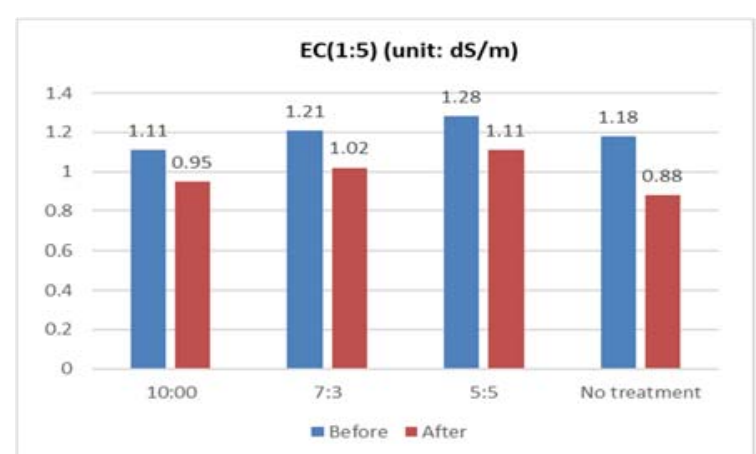

(b) EC (1:5)

Figure 5. Chemical properties of soil in different mix-treated plots. (a) $\mathrm{pH}(1: 5)$ and (b) EC: electrical conductivity (EC; 1:5).

$\mathrm{P} 2 \mathrm{O} 5, \mathrm{~K}, \mathrm{Ca}$, and $\mathrm{Mg}$ had reactions such as upward or downward movement to the standard of suitable ingredient of soil (Figure 6). P2O5 is an available phosphorus form responsible for strengthening the roots and stems. The available phosphorus of the soil is analyzed to determine the amount of phosphorus fertilizer applied. Available phosphorus refers to the phosphorus forms that can be absorbed by crops; however, the amount of phosphorus that plants can absorb may be insufficient even if the amount of available phosphorus is high, thus phosphorus fertilizer is added. A large amount of available phosphorus in the soil does not have a significant effect on the crop. However, the phosphorus can dissolve in the water during rain and flow into rivers, causing eutrophication and groundwater pollution, or binding with and insolubilizing trace elements, thus causing trace element deficiencies in crops. In general, the phosphorus content of Korean soils is almost five times higher than the ideal value (mean: $986 \mathrm{mg} \mathrm{kg}^{-1}$, maximum: $2510 \mathrm{mg} \mathrm{kg}^{-1}$ ) [62], which is due to sustained fertilizer use. The P2O5 content indicated in Figure 6 is significantly lower than that of the Korean facility cultivation (mean: $986 \mathrm{mg} \mathrm{kg}^{-1}$ ), but still exceeded the threshold by up to two times. K content affects moisture content and cell size, which decrease due to low K concentration. Figure 6 shows that the 10:0 mix-treated plot had the most appropriate $\mathrm{K}$ content before the experiment. Moreover, the $\mathrm{K}$ content in all plots were lower than the threshold. 


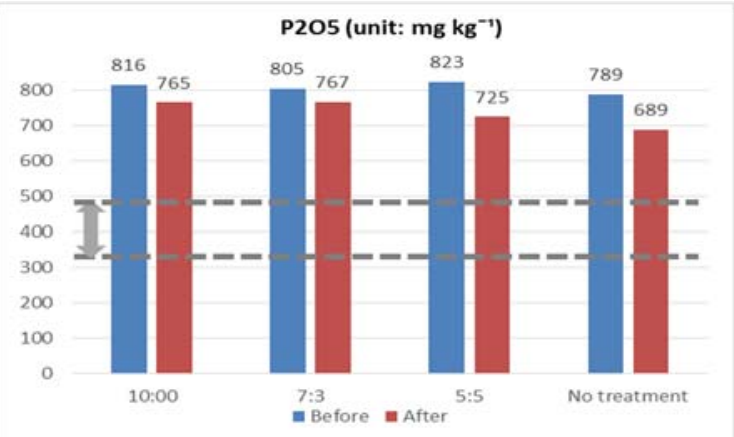

(a)

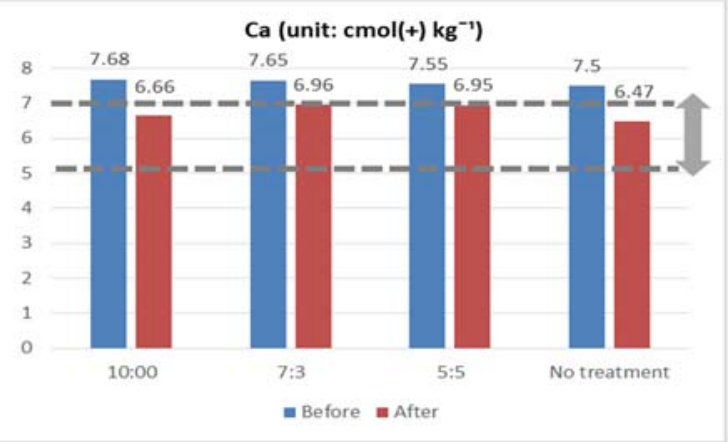

(c)

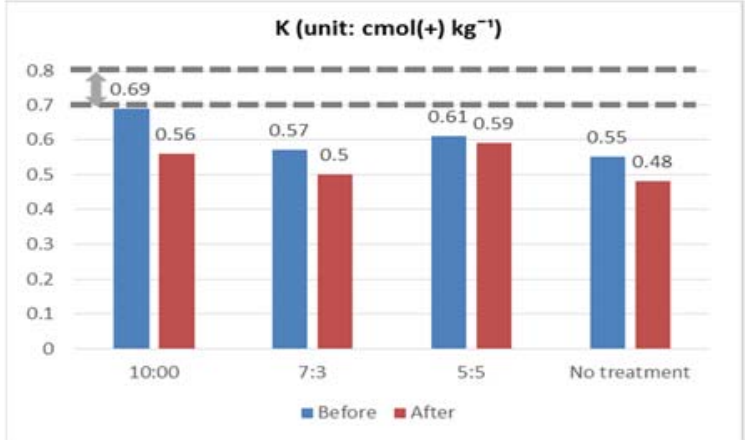

(b)

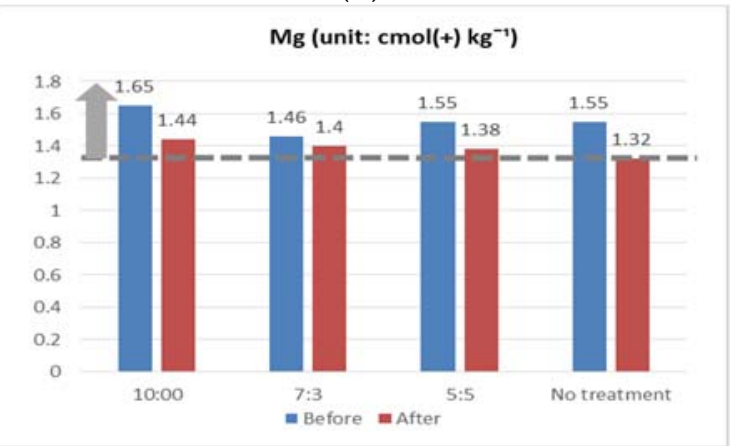

(d)

Figure 6. Chemical properties of soil in different mix-treated plots. (a) P2O5, (b) K, (c) Ca, and (d) Mg.

Ca prevents soil acidification. According to some studies, Jeju Island soil has high $\mathrm{K}$ and low Ca contents [63]. Due to the lack of Ca in Jeju soil, carbonized tangerines are likely appropriate for improving the soil quality in Jeju. Additionally, considering the experimental results for Ca content, the value higher than the standard before the experiment was adjusted to within the normal range after the experiment. Residual Ca was higher in coco peat-treated plots than that in untreated plots. $\mathrm{Mg}$ is involved in the overall crop growth and $\mathrm{Mg}$ deficiency causes yellowing and browning necrosis in plants. $\mathrm{Mg}$ content was similar before and after the experiment, but the content in plots treated with high carbonized material was close to the threshold.

The changes in OM, CEC, and T-N were mixed (Figure 7). The OM of all treated plots tended to decrease after the experiment, but only that of the untreated plot increased. The nutrient retention capacity increases with the increase in CEC and the CEC of all coco peat-treated plots tended to decrease after the experiment even in minor amounts; however, it tended to increase in other plots. In other words, CEC showed a tendency to increase only in the 10:0 mix-treated plots after the experiment. All T-N values tended to decrease after the experiment.

\subsubsection{Comparison among Untreated, 10:0 Mix-Treated, and Chaff Charcoal-Treated Plots}

The $\mathrm{pH}(1: 5)$ was in the appropriate range for the untreated, mix-treated, and control plots (Figure 8) and was no significant change after treatment. EC (1:5) also did not change significantly within the normal range in all plots.

$\mathrm{P} 2 \mathrm{O} 5, \mathrm{~K}, \mathrm{Ca}$, and $\mathrm{Mg}$ exhibited reactions such as upward or downward movement to the standard of suitable ingredients of soil (Figure 9). P2O5 content, which is the available phosphorus, was significantly lower than that of the Korean facility cultivation as indicated in Figure 10 but exceeded the threshold by up to two times.

$\mathrm{K}$ content was lower than the threshold similar to Figure 10 in the experimental results. However, it was higher in the treated and control plots than that in the untreated plot. K content affected lettuce weight, which was higher in the treated and control plots than that in the untreated plot. 


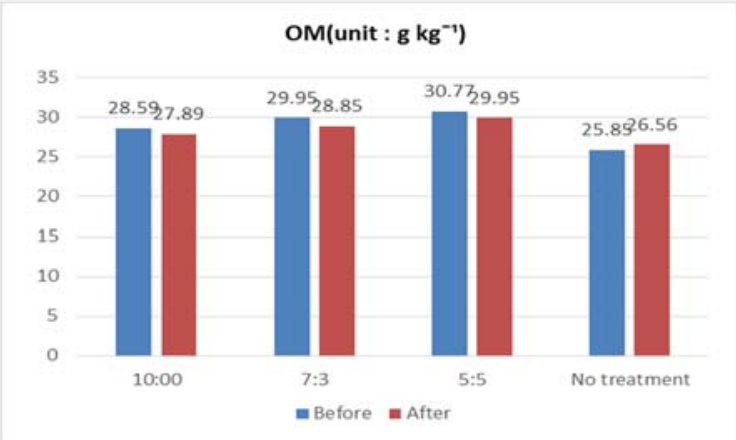

(a) $\mathrm{OM}$

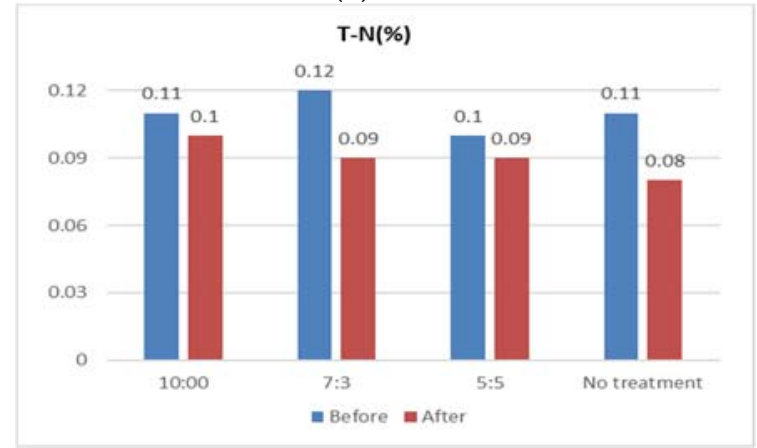

(c) T-N

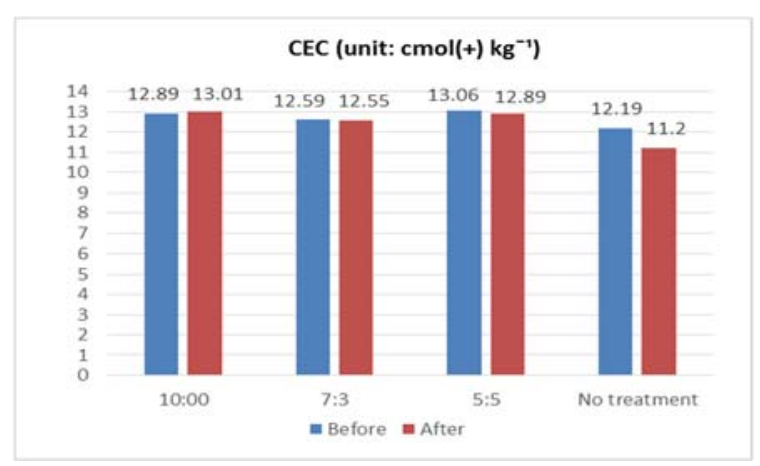

(b) CEC

Figure 7. Chemical properties of soil in different mix-treated plots. (a) organic matter (OM), (b) cationexchange capacity (CEC), and (c) total nitrogen (T-N).

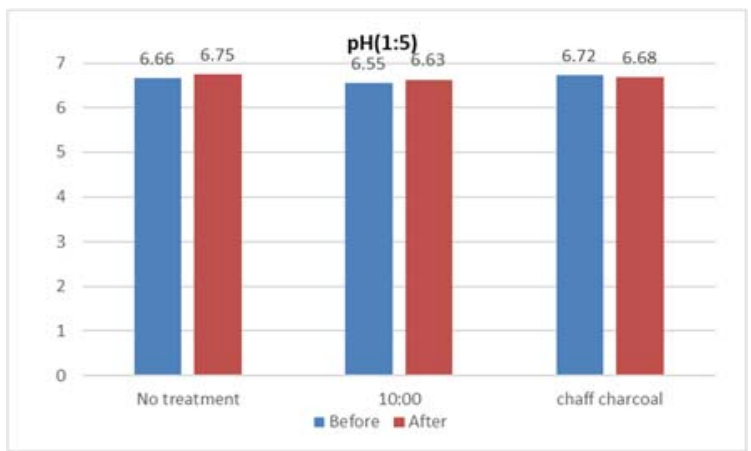

(a) $\mathrm{pH}(1: 5)$

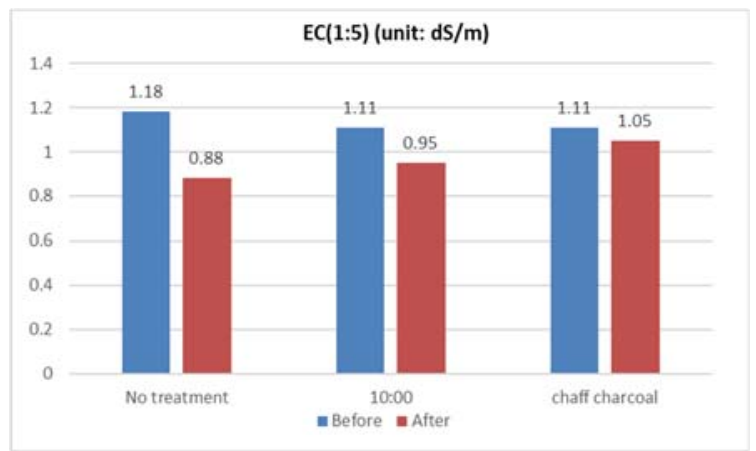

(b) EC (1:5)

Figure 8. Chemical properties of soil in untreated, 10:0 mix-treated, and chaff charcoal-treated plots. (a) $\mathrm{pH}(1: 5)$ and (b) electric conductivity (EC; $1: 5)$.

According to the current results, the Ca content, which was higher than the threshold before the experiment, was adjusted to within the normal range after the experiment in the untreated and treated plots. In the control plot, $\mathrm{Ca}$ content tended to decrease; consequently, it is desirable to use chaff charcoal as a control method in soil lacking Ca. Mg contents before and after the experiment are similar. Maintaining the appropriate range after the experiment was determined as a control.

The OM and CEC changes in the untreated, 10:0 mix-treated, and chaff char-coaltreated plots differed. OM increase in the treated plots was more than that in the un-treated plot even after the experiment, and the trends of OM in the chaff charcoal-treated plot were reversed. Increased CEC is associated with high nutrient retention capacity. Even after the experiment, the CEC of the treated and control plots were high, indicating a high level of nutrient retention capacity of the soil. 


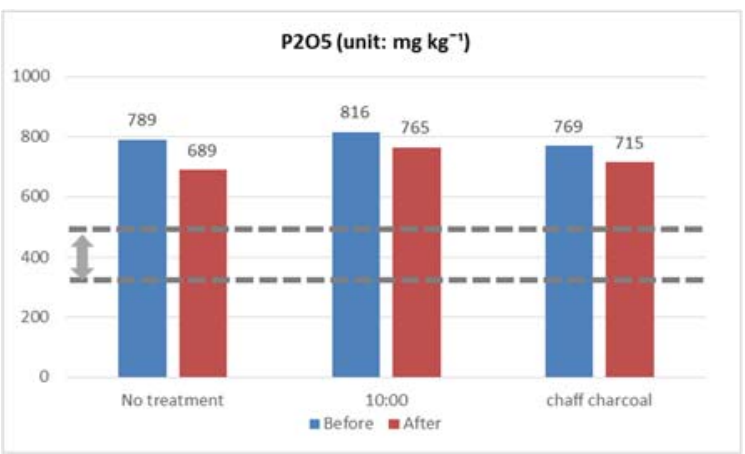

(a)

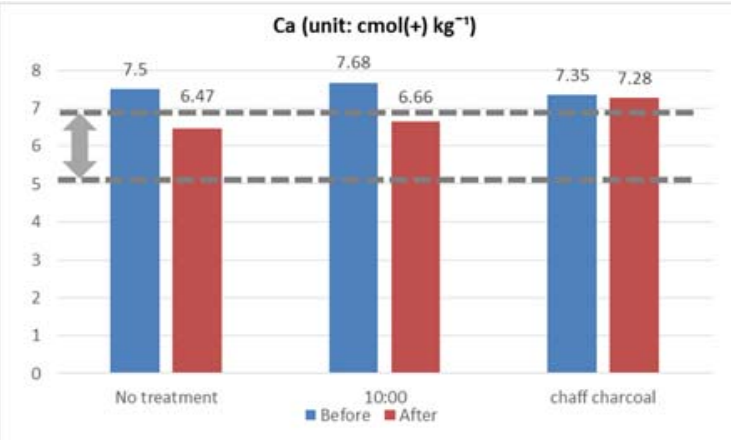

(c)

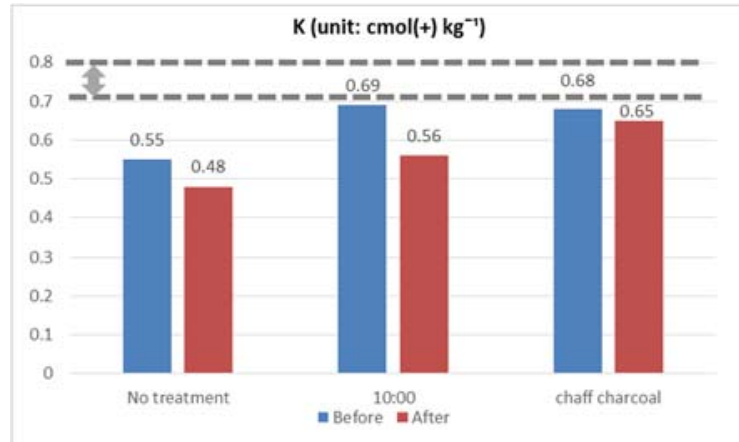

(b)

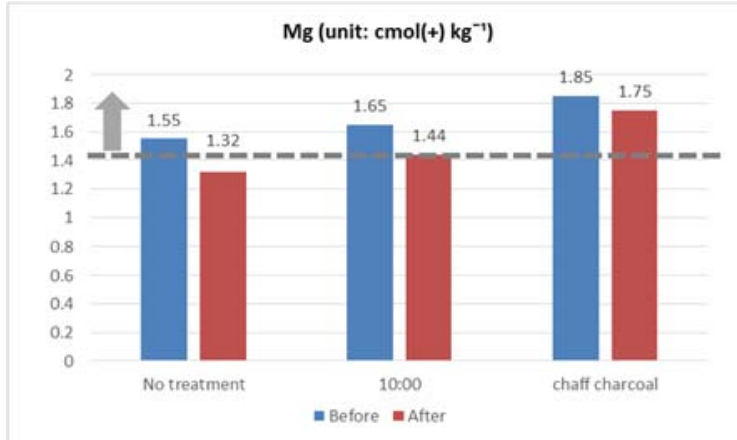

(d)

Figure 9. Chemical properties of soil in untreated, 10:0 mix-treated, and chaff charcoal-treated plots. (a) P2O5, (b) K, (c) Ca, and (d) Mg.

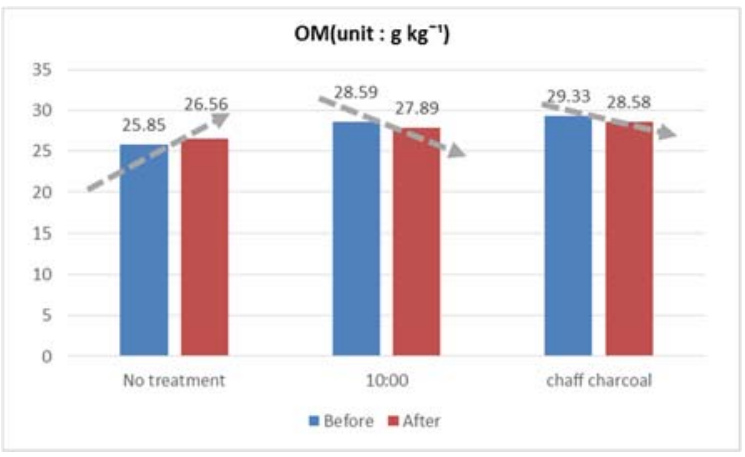

(a) $\mathrm{OM}$

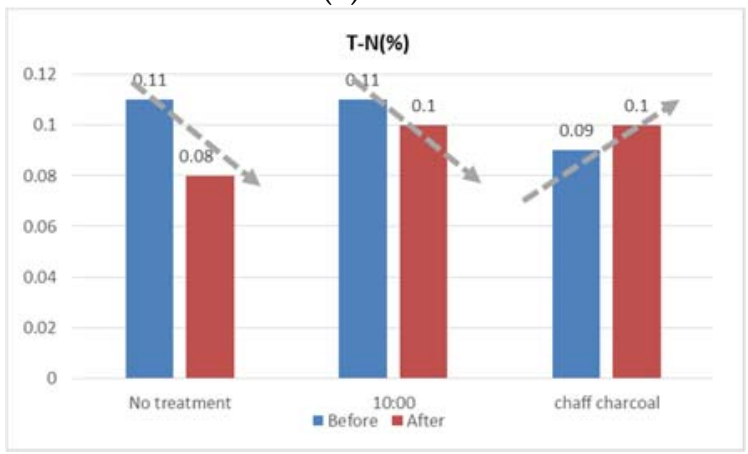

(c) T-N

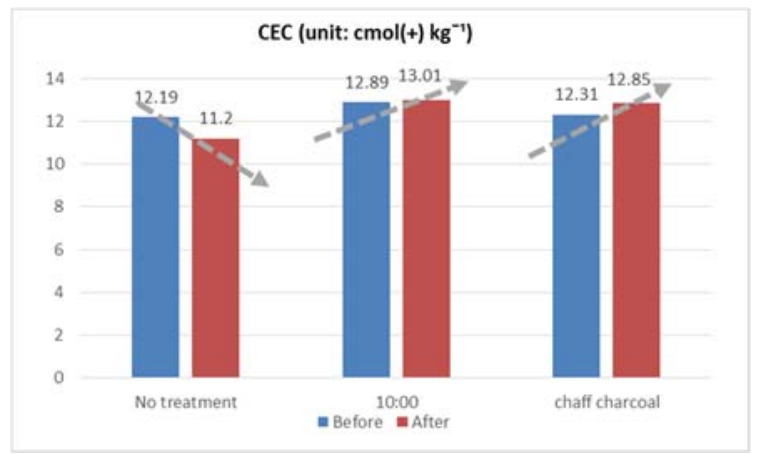

(b) CEC

Figure 10. Chemical properties of soil in untreated, 10:0 mix-treated, and chaff charcoal-treated plots. (a) organic matter (OM), (b) cation-exchange capacity (CEC), and (c) total nitrogen (T-N).

The T-N of the untreated and 10:0 mix-treated plots had a similar tendency to decrease after the experiment. In contrast, it increased in the chaff charcoal-treated plot. The T-N 
of the 10:0 mix- and chaff charcoal-treated plots after the experiment were identical and higher than that of the untreated plot.

The chemical properties of soil in untreated, 10:0 mix-treated, and chaff charcoaltreated plots were not significantly different before and after the experiment. However, some significant changes were observed in $\mathrm{K}$ content, which determines plant growth quality, and Ca content, which prevents soil acidity. The OM index and CEC of the 10:0 mix- and chaff charcoal-treated plots had similar trends.

\section{Discussion}

When carbonized materials were mixed, the concentrations of some ions before the experiment were above or below the optimal range, but there was a tendency to return to an acceptable level throughout the experiment. Moreover, no salt was accumulated.

Considering the change in growth characteristics, the average value of leaf length increased in all plots except the untreated plot. This increase in all treatment plots was statistically significant, indicating increased growth. The leaf length increased the most in the 10:0 mix-treated plot. Leaf width showed an evident tendency to increase in the treated plots than that in the untreated plot, and the highest increase was observed in the 10:0 mix-treated plot.

Similar to leaf length and leaf width, leaf weight tended to increase in all treated plots than that in the untreated plot, and the highest increase was observed in the 10:0 mix-treated plot. However, the leaf counts in the untreated and 10:0 mix-treated plots were similar, though it statistically increased in the remaining treated plots than that in the un-treated plot. The chlorophyll content, measured thrice at the center of the longest lettuce leaf, was the lowest in the 10:0 mix-treated plot and high in the other treated plots. How-ever, the yield increased by $34.4 \mathrm{~g}$ in the 10:0 mix-treated plot than that in other treated plots, and the growth increased in the carbonized tangerine- and chaff charcoal-treated plots.

The analysis of the chemical composition of the soil before and after the treatment with carbonized tangerines and chaff charcoal indicated that the $\mathrm{pH}$ in the soil was not significantly changed before and after the test, and the EC was similar to the pre-treatment level or slightly decreased. In addition, the other parameters analyzed did not deviate significantly from the optimal level. Thus, the chemical changes in the soil before and after treatment was not significant.

These results indicate that the physical and chemical components of the carbonized tangerine- and chaff charcoal-treated plots positively affect lettuce leaf growth. Consequently, the yield was substantially higher than that in the untreated plot. However, the value for some elements in the 5:5 mix-treated plot was higher than that in the 7:3 mixtreated plot. Accordingly, an in-depth investigation is required in future studies. Herein, we only considered the possibility of their application as a fertilizer. However, their economic feasibility needs to be confirmed so that farmers can create additional profit by seeking various ways to use carbonized tangerines as biochar in the future.

\section{Conclusions}

Treatment with carbonized tangerines and chaff charcoal during the growing period favored leaf growth and enhanced crop growth by enhancing the mobility of nutrient products, thereby resulting in a healthy product and yield. Through this study, the carbonization of fallen tangerines using plasma revealed the following results while treating numerous by-products generated during tangerine cultivation and processing. First, the carbonization of approximately $200 \mathrm{~kg}$ tangerines using plasma produced approximately $3 \mathrm{~kg}$ carbonized by-products, with approximately $98 \%$ mass reduction rate. Second, the remaining byproducts can possibly be used as fertilizer instead of being treated as waste. Therefore, the possibility of substantially reducing organic waste generated from harvesting a single crop was demonstrated in this study. As a result, it was found that the by-product of tangerine carbonization using plasma is helpful through the lettuce cultivation experiment, and the by-products can be used in the level of fertilizer. 
Author Contributions: S.-Y.M. and H.S.K. conducted the data and designed the research. S.-Y.M., D.J. and J.-Y.L. drafted and revised the manuscript based on the research results. All authors have read and agreed to the published version of the manuscript.

Funding: This study was supported by a grant [21AUDP-B146511-4] from the Architecture \& Urban Development Research Program funded by the Ministry of Land, Infrastructure and Transport of the Korean government.

Acknowledgments: The production of carbonized tangerines was supported by Vitzro Tech.

Conflicts of Interest: The authors declare no conflict of interest.

\section{References}

1. Convention on the Prevention of Marine Pollution by Dumping of Wastes and Other Matter. 1996. Available online: https:/ / www.imo.org/en/About/Conventions/Pages/Convention-on-the-Prevention-of-Marine-Pollution-by-Dumping-ofWastes-and-Other-Matter.aspx (accessed on 22 September 2021).

2. Choi, Y. Customized Biochar Production Technology for Environmental Applications; Konetic Report No. 16; Korea Environmental Industry Technology Institute: Seoul, Korea, 2017; p. 6.

3. Tan, Z.; Qiu, J.; Zeng, H.; Liu, H.; Xiang, J. Removal of elemental mercury by bamboo charcoal impregnated with H2O2. Fuel 2010, 90, 1471-1475. [CrossRef]

4. Xue, Y.; Gao, B.; Yao, Y.; Inyang, M.; Zhang, M.; Zimmerman, A.R.; Ro, K.S. Hydrogen peroxide modification enhances the ability of biochar (hydrochar) produced from hydrothermal carbonization of peanut hull to remove aqueous heavy metals: Batch and column tests. Chem. Eng. J. 2012, 200, 673-680. [CrossRef]

5. Zhou, Y.; Gao, B.; Zimmerman, A.R.; Fang, J.; Sun, Y.; Cao, X. Sorption of heavy metals on chitosan-modified biochars and its biological effects. Chem. Eng. J. 2013, 231, 512-518. [CrossRef]

6. Stavropoulos, G.G.; Samaras, P.; Sakellaropoulos, G.P. Effect of activated carbons modification on porosity, surface structure and phenol adsorption. J. Hazard. Mater. 2008, 151, 414-421. [CrossRef] [PubMed]

7. Jing, X.-R.; Wang, Y.-Y.; Liu, W.-J.; Wang, Y.-K.; Jiang, H. Enhanced adsorption performance of tetracycline in aqueous solutions by methanol-modified biochar. Chem. Eng. J. 2014, 248, 168-174. [CrossRef]

8. Ghaffar, A.; Younis, M. Adsorption of organic chemicals on graphene coated biochars and its environmental implications. Green Process. Synth. 2014, 3, 479-487. [CrossRef]

9. Zhang, M.; Gao, B.; Yao, Y.; Xue, Y.; Inyang, M. Synthesis, characterization, and environmental implications of graphene-coated biochar. Sci. Total Environ. 2012, 435, 567-572. [CrossRef]

10. Yao, Y.; Gao, B.; Fang, J.; Zhang, M.; Chen, H.; Zhou, Y.; Creamer, A.E.; Sun, Y.; Yang, L. Characterization and environmental applications of clay-biochar composites. Chem. Eng. J. 2014, 242, 136-143. [CrossRef]

11. Wang, S.; Gao, B.; Zimmerman, A.R.; Li, Y.; Ma, L.; Harris, W.G.; Migliaccio, K.W. Removal of arsenic by magnetic biochar prepared from pinewood and natural hematite. Bioresour. Technol. 2015, 175, 391-395. [CrossRef]

12. Yao, Y.; Gao, B.; Chen, J.; Zhang, M.; Inyang, M.; Li, Y.; Alva, A.; Yang, L. Engineered carbon (biochar) prepared by direct pyrolysis of Mg-accumulated tomato tissues: Characterization and phosphate removal potential. Bioresour. Technol. 2013, 138, 8-13. [CrossRef]

13. Song, Z.; Lian, F.; Yu, Z.; Zhu, L.; Xing, B.; Qiu, W. Synthesis and characterization of a novel MnOx-loaded biochar and its adsorption properties for $\mathrm{Cu} 2+$ in aqueous solution. Chem. Eng. J. 2014, 242, 36-42. [CrossRef]

14. Hwang, S.J.; Jeong, B.R. Use of CGF and CCW as medium components for commercial production of plug seedlings of Seogun Tomato. J. Bio-Environ. Control. 2004, 13, 81-89.

15. Lee, S.B.; Hong, S.G.; Park, K.L.; Kim, J.H.; Nam, H.S.; Kim, S.C. Effects of biochar application for organic potatoes and Chinese cabbage cultivation. Korean Soc. Soil Sci. Fertil. 2014, 10, 201-202.

16. Park, D.G.; Hong, S.G.; Jang, E.S.; Shin, J.D. Assessment of an optimum biochar application rate for tomato. J. Korea Organ. Resour. Recycl. Assoc. 2019, 27, 39-48.

17. Seo, D.C.; Guo, R.; Lee, D.H. Removal of odor by alkaline carbonized agricultural byproduct. Korean Soc. Waste Manag. 2017, 118. Available online: https:/ / www.kswm.or.kr (accessed on 23 October 2021).

18. Rhie, Y.H.; Kang, S.H.; Choi, J.M.; Kim, J.Y. Physical and chemical properties of bottom ash and coir dust mix used as horticultural substrates. Korean J. Hortic. Sci. Technol. 2018, 161-171.

19. Park, D.G.; Shin, J.D. Effects of blended biochar pellet on the change of soil chemical properties for corn (Zea mays) cultivation. Korean Soc. Environ. Agric. 2020, 864, 012100.

20. Dodor, D.E.; Amanor, Y.J.; Attor, F.T.; Adjadeh, T.A.; Neina, D.; Miyittah, M. Co-application of biochar and cattle manure counteract positive priming of carbon mineralization in a sandy soil. Environ. Syst. Res. 2018, 7, 5. [CrossRef]

21. Shinogi, Y.; Yoshida, H.; Koizumi, T.; Yamaoka, M.; Saito, T. Basic characteristics of low-temperature carbon products from waste sludge. Adv. Environ. Res. 2002, 7, 661-665. [CrossRef]

22. Uzoma, K.C.; Inoue, M.; Andry, H.; Fujimaki, H.; Zahoor, A.; Nishihara, E. Effect of cow manure biochar on maize productivity under sandy soil condition. Soil Use Manag. 2011, 27, 205-212. [CrossRef] 
23. Baldock, J.A.; Smernik, R.J. Chemical composition and bioavailability of thermally altered Pinus resinosa (red pine) wood. Org. Geochem. 2002, 33, 1093-1109. [CrossRef]

24. Chan, K.Y.; Van Zwieten, L.; Meszaros, I.; Downie, A.; Joseph, S. Agronomic values of greenwaste biochar as a soil amendment. Soil Res. 2007, 45, 629-634. [CrossRef]

25. Chan, K.Y.; Van Zwieten, L.; Meszaros, I.; Downie, A.; Joseph, S. Using poultry litter biochars as soil amendments. Soil Res. 2008, 46, 437-444. [CrossRef]

26. Glaser, B.; Lehmann, J.; Zech, W. Ameliorating physical and chemical properties of highly weathered soils in the tropics with charcoal-A review. Biol. Fertil. Soil 2002, 35, 219-230. [CrossRef]

27. Rondon, M.A.; Lehmann, J.; Ramirez, J.; Hurtado, M. Biological nitrogen fixation by common beans (Phaseolus vulgaris L.) increases with bio-char additions. Biol. Fertil. Soil 2007, 43, 699-708. [CrossRef]

28. Park, J.Y. Report on Soil Remediation and Carbon Sequestration Analysis Using Biochar; Kinetic-Report No. 148; Ministry of Environment, Korea Environmental Industry \& Technology Institute: Sejong, Korea, 2016.

29. Lehmann, J.; Gaunt, J.; Rondon, M. Bio-char sequestration in terrestrial ecosystems-A review. Mitig. Adapt. Strateg. Glob. Chang. 2006, 11, 403-427. [CrossRef]

30. Woolf, D.; Amonette, J.E.; Street-Perrott, F.A.; Lehmann, J.; Joseph, S. Sustainable biochar to mitigate global climate change. Nat. Commun. 2010, 1, 56. [CrossRef]

31. Lin, Y.-J.; Hwang, G.-S. Charcoal from biomass residues of a Cryptomeria plantation and analysis of its carbon fixation benefit in Taiwan. Biomass Bioenergy 2009, 33, 1289-1294. [CrossRef]

32. Yanai, Y.; Toyota, K.; Okazaki, M. Effects of charcoal addition on N2O emissions from soil resulting from rewetting air-dried soil in short-term laboratory experiments. Soil Sci. Plant Nutr. 2007, 53, 181-188. [CrossRef]

33. Kammann, C.; Ippolito, J.; Hagemann, N.; Borchard, N.; Cayuela, M.L.; Estavillo, J.M. Biochar as a tool to reduce the agricultural greenhouse-gas burden-Knowns, unknowns and future research needs. J. Environ. Eng. Landsc. Manag. 2017, 25, 114-139. [CrossRef]

34. Rondon, M.; Ramirez, J.; Lehmann, J. Greenhouse Gas Emissions Decrease with Charcoal Additions to Tropical Soils. In Proceedings of the 3rd USDA Symposium on Greenhouse Cased and Carbon Sequestration, Baltimore, MD, USA, 21-24 March 2005; p. 208.

35. Van Zwieten, L.; Kammann, C.I.; Cayuela, M.L.; Singh, B.P.; Joseph, S.; Kimber, S.; Donne, S.; Clough, T.J.; Spokas, K. Biochar effects on nitrous oxide and methane emissions from soil. In Biochar For Environmental Management-Science, Technology and Implementation, 2nd ed.; Lehmann, J., Joseph, S., Eds.; Routledge: New York, NY, USA, 2015.

36. Cayuela, M.L.; Van Zwieten, L.; Singh, B.P.; Jeffery, S.; Roig, A.; Sánchez-Monedero, M.A. Biochar's role in mitigating soil nitrous oxide emissions: A review and meta-analysis. Agric. Ecosyst. Environ. 2014, 191, 5-16. [CrossRef]

37. Scheer, C.; Grace, P.R.; Rowling, D.W.; Kimber, S.; Van Zwieten, L. Effect of biochar amendment on the soil-atmosphere exchange of greenhouse gases from an intensive subtropical pasture in northern New South Wales, Australia. Plant Soil 2011, 345, 47-58. [CrossRef]

38. Sanchez-Garcial, M.; Sanchez-Monedero, M.A.; Roig, A.; Lopez-Cano, I.; Moreno, B.; Benitez, E.; Cayuela, M.L. Compost vs biochar amendment: A two-year field study evaluating soil $\mathrm{C}$ build-up and $\mathrm{N}$ dynamics in an organically managed olive crop. Plant Soil 2016, 408, 1-14. [CrossRef]

39. Splokas, K.A.; Reicoscoky, D.A. Impacts of sixteen different biochars on soil greenhouse gas production. Ann. Environ. Sci. 2009, 3, 179-193.

40. Clough, T.J.; Bertram, J.E.; Ray, J.L.; Condron, L.M.; O'Callaghan, M.; Sherlock, R.R.; Wells, N.S. Unweathered wood biochar impact on nitrous oxide emissions from a bovine-urine-amended pasture soil. Soil Sci. Soc. Am. J. 2010, 74, 852-860. [CrossRef]

41. Saarnio, S.; Heimonen, K.; Kettunen, R. Biochar addition indirectly affects N2O emissions via soil moisture and plant N uptake. Soil Biol. Biochem. 2013, 58, 99-106. [CrossRef]

42. Troy, S.M.; Lawlor, P.G.; O' Flynn, C.J.; Healy, M.G. Impact of biochar addition to soil on greenhouse gas emissions following pig manure application. Soil Biol. Biochem. 2013, 60, 173-181. [CrossRef]

43. Qian, L.; Chen, L.; Joseph, S.; Pan, G.; Li, L.; Zheng, J.; Zhang, X.; Zheng, J.; Yu, X.; Wang, J. Biochar compound fertilizer as an option to reach high productivity but low carbon intensity in rice agriculture of China. Carbon Manag. 2014, 5, 145-154. [CrossRef]

44. Jeffery, S.; Verheijen, F.G.; Kammann, C.; Abalos, D. Biochar effects on methane emission from soils: A meta-analysis. Soil Biol. Biochem. 2016, 101, 251-258.

45. Lin, X.; Xie, Z.; Zheng, J.; Liu, Q.; Bei, Q.; Zhu, J. Effects of biochar application on greenhouse gas emissions, carbon sequestration and crop growth in coastal saline soil. Eur. J. Soil Sci. 2015, 66, 329-338. [CrossRef]

46. Choi, J.; Shinde, P.; Kwon, I.; Song, Y.; Chae, B. Effect of wood vinegar on the performance, nutrient digestibility and intestinal microflora in weanling pigs. Asian-Aust. J. Anim. Sci. 2009, 22, 267-274. [CrossRef]

47. Islam, M.M.; Ahmed, S.T.; Kim, Y.J.; Mun, H.S.; Kim, Y.J.; Yang, C.J. Effect of sea tangle (Laminaria japonica) and charcoal supplementation as alternatives to antibiotics on growth performance and meat quality of ducks. Asian-Aust. J. Anim. Sci. 2014, 27, 217-224. [CrossRef]

48. Glaser, B.; Weidner, K.; Seelig, S.; Schmidt, H.P.; Gerber, H. Biochar organic fertilizers from natural resources as substitute for mineral fertilizers. Agron. Sustain. Dev. 2014, 35, 667-678. [CrossRef] 
49. Karim, A.A.; Kumar, M.; Mohapatr, S.; Singh, S.K. Nutrient rich biomass and effluent sludge wastes co-utilization for production of biochar fertilizer through different thermal treatments. J. Clean. Prod. 2019, 228, 570-579. [CrossRef]

50. Karim, A.A.; Kumar, M.; Singh, S.K.; Panda, C.R. Potassium enriched biochar production by thermal plasma processing of banana peduncle for soil application. J. Anal. Appl. Pyrolysis 2017, 123, 165-172. [CrossRef]

51. Zhang, H.; Wang, T.; Sui, Z.; Zhang, Y.; Norris, P.; Sum, B.; Pan, W. Plasma induced addition of active functional groups to biochar for elemental mercury removal. Plasma Chem. Plasma Process. 2019, 39, 1449-1468. [CrossRef]

52. Akhil, D.; Lakshmi, D.; Kartik, A.; Vo, D.; Arun, J.; Gopinath, K.P. Production, characterization, activation and environmental applications of engineered biochar: A review. Environ. Chem. Lett. 2021, 19, 2261-2297. [CrossRef]

53. Inayat, A.; Tariq, R.; Khan, Z.; Ghenai, C.; Kamil, M.; Jamil, F.; Shanableh, A. A comprehensive review on advanced thermochemical processes for bio-hydrogen production via microwave and plasma technologies. Biomass Convers. Biorefinery 2020, 1-10. [CrossRef]

54. Soil Contamination Process Test Standards; Korean Government Law Code No. 2018-53; The Ministry of Environment of Korea: Sejong, Korea, 2018.

55. Agricultural Science and Technology Research Analysis Standards; Korean Government Law Code No. 2017-12; Rural Development Administration, National Institute of Agricultural Sciences: Jeon-Ju, Korea, 2017; Available online: www.nongsaro.go.kr (accessed on 13 January 2021).

56. Notification on Method and Procedure for Measurement and Calculation of Energy Recovery Efficiency; Notification No. 2019-62; Ministry of Environment: Sejong, Korea, 2019.

57. Kim, H.S.; Jung, S.; Ho, R.B.; Hwang, L.H.; Choi, M.G.; Park, S.H.; Cho, Y.W.; Park, H.K.; Jang, D.; Moon, S.Y.; et al. Food Waste Treatment System Using Plasma Torch And Food Waste Treatment Method Using the Same. Korean Patent Number 10-1718008, 2017.

58. Standard Operating Procedure (SOP) for Food Waste Management to Counteract African Swine Fever; Ministry of Environment: Sejong, Korea, 2019.

59. Korea Institute of Fusion Energy. 2012. Available online: https://www.kfe.re.kr/kor/post/research_result/6170 (accessed on 28 May 2021).

60. Progress Standard-Setting and Designation; Korean Government; Law Code No. 2020-40; Rural Development Administration, National Institute of Agricultural Sciences: Jeon-Ju, Korea, 2020; Available online: www.nongsaro.go.kr (accessed on 13 January 2021).

61. Nam, K.-H.; Ko, E.M.; Mun, S.; Kim, C.-G. Measuring leaf areas with a structured-light 3D scanner. Korean J. Ecol. Environ. 2014, 47, 232-238. [CrossRef]

62. Introduction of Material for Organic Food Production. Available online: http://www.heuk.or.kr/data/heuksalimEnglish.pdf (accessed on 18 November 2020).

63. Fertilizer Prescription Program Utilization Manual; Public No. 11-1390802-000551-01; Rural Development Administration, National Institute of Agricultural Sciences: Jeon-Ju, Korea, 2013; Available online: www.nongsaro.go.kr (accessed on 13 January 2021). 